\title{
ANALYSIS GRAMMATICAL ERRORS IN USING SIMPLE PRESENT TENSE IN WRITING DESCRIPTIVE TEXT
}

\author{
Zahro Salsabila $^{1}$, Muthia Mubasyira ${ }^{2}$ \\ 1,2Universitas Indraprasta PGRI, English Education Program, Campus A, Building 1, 2nd Floor \\ Jl. Nangka No. 58 C Kel. Tanjung Barat, Kec. Jagakarsa, Jakarta Selatan 12530, Jakarta, Indonesia.
}

Corresponding Author(S): muthia.mubasyira@yahoo.com

\begin{abstract}
:
One of the English skills which are important to be mastered by the students is writing skill. Writing is a creative and expressive process. Students need to explore their ideas and compose them into a good text. The objectives of this research are to find out types of error and the most dominant error writing using simple present tenses in a descriptive text.
\end{abstract}

Keywords:

Errors Analysis, simple Present Tense, descriptive Text

\section{INTRODUCTION}

As we know, English may be a language that's recognized as a universal language in the world. In fact, in line with (Zawahreh, 2012) to search out what's happening to the world just like the economy, politics, and technological development, we must

understand and learn English. Therefore, in Indonesia, English has an important role and one of the subjects taught in schools. In learning English, guidelines of the school-based Curriculum (KTSP) which is applied for all school levels in Indonesia lead the students to have real-life skills. This implies that teaching English stated in KTSP, in particular, is to enable students to master the four language skills, which are listening, speaking, reading, and writing. Writing is one of the foremost vital skills that have to be learned by students, accustomed give factual, persuasive, and fun data by expressing concepts, opinions that are unit organized consistently and following sure rules.

In writing, the students still have hesitancy concerning descriptive linguistics. Since descriptive linguistics is that the basic part of an area of information or ability, or it is a set of prescriptive notions about the correct use of a language. According to linguist, Chomsky (1986) grammar is the limitation that makes us able to produce a sentence that is correct so that it can be understood by the listener and reader. Therefore, it is very important for the students to pay attention to grammar when they are writing.

English has many tenses; simple present tense is one of them. The simple present tense is important as the basic rule for the students to make and use sentences in writing. The simple present is employed to explain routines or habits. It is also used to express opinions 
or make general statements (Werner, 2013). In line with this definition, Reutzel \& Schoenberg (2006) explains that the simple present is used to show actions, events, or states that happen habitually or as a general rule.

There are three types of English writing like description, narration, and exposition. The description is writing about a person, animal, thing, or place that appears. According to Knapp and Watkins (2005), descriptive is a type of text aimed to describe a particular person, place, or thing. So, descriptive text may be a text that presents data concerning one thing.

The students were still made errors when write descriptive text. it is very possible to happen to foreign language learners. This is as expressed by James (1998) that error analysis is the process of determining the reason for language failure. By analyzing the students' error, it will give the important role in giving the feedback for the teacher in order to evaluate and develop the material in teaching learning process.

The classification is very important to explain the error analysis. According to Dulay, Burt and Krashen. (1982: 150-163) there are four categories of error based on the surface strategy taxonomy.

Types Of Errors, surface strategy taxonomy focuses on the ways that learners may omit essential items or add inessential ones; learners may mis-form items or mis-order them. This type of errors into four components: (1) Omission, omission can also be called a deletion. Omission errors are characterized by the absence of an item that has to seem in a grammatical sentence or vocalization. as an example, in the sentence Marry president new company. The good form sentence is Marry is the president of the new company. As we all know that morphemes or words may be distinguished into two classes: content words and grammatical words. Content words are unit those who carry the majority of the denotative that means of a sentence. Grammatical or function words are unit those very little words that play a bit part in carrying that means of a sentence, (2) Addition, addition errors are characterized by the presence of an item that must not appear in a wellformed construction. It usually occurs in the later stages of second language learning, when the learner has already acquired some target language rules. There are three kinds of addition errors: Double marking, for example, He doesn't know my name; Regularization, for example, the verb eat does not become ate but ate; Simple addition, for example, the fishes don't live in the water, (3) Mis-formation, mis-formation errors are characterised by the use of the incorrect style of the morpheme or structure. It happens when the learner provides one thing though it's incorrect. They are three types of misformation errors: Regularizations, for example, runed for ran; Archi-form, for example: that cats it should be those cats; Alternating forms, for example, her for she. (4) Misordering, mis-ordering errors are characterised by the wrong placement of a morpheme or cluster of morphemes during construction. This type of error may be caused by the word, for word translation of language surface structure. For example, what Daddy is doing? It should be what is Daddy doing? 


\section{METHOD}

This analysis was designed as a descriptive qualitative method. Qualitative methods are thought acceptable to clarify information in the kind of text obtained from respondents in detail. As explained by Moleong in Aryo (2017) that qualitative analysis is an analysis that aims to know what phenomena are practiced by analyzing subjects like motivation, action, perception, and et al. By means that of descriptions in the kind of words in a specific context and technique natural. During this case, the researchers used a taxonomy surface strategy to research grammatical errors, especially simple present in descriptive text.

The object of this research is descriptive text made by the 4th semester students of Yogyakarta PGRI University. In one class studied there have been eight students. Additionally, analysis instruments are required that finally written descriptive text written by students is chosen by researchers to be an instrument during this study. Researchers additionally give 3 themes so students aren't confused and create it easier for them to write down. The themes are "Family", "Best Destination in Indonesia" and "My Idol". The first step the researcher did was to ask all students to write descriptive text by choosing one of the predetermined themes. The next step is to analyze the data by recognizing which sentences use simple present correctly and also looking for which sentences have errors. After obtaining an error sentence data, the researcher classifies the type of error again using a surface strategy taxonomy. Whether the error is included in omission, addition, mis-formation, or mis-ordering. The researcher also calculates the frequency of each error that occurs. To calculate what percentage of the number of errors occur, researchers use the percentage formula as follows:

$$
P \frac{n 1}{\sum N} \times 100 \%
$$

P: Percentage of each error $\mathrm{n} 1$ : Total of the given error

$\sum \mathrm{N}$ : Total of the whole error

\section{RESULTS AND DISCUSSION}

The results of the study are listed within the table below:

Table 1 Results of the study

\begin{tabular}{llll}
\hline Total of Students & Total Simple Present Tense & $\begin{array}{l}\text { The Correct Use of Simple } \\
\text { Present Tense }\end{array}$ & $\begin{array}{l}\text { Total Errors in Using } \\
\text { Simple Present Tense }\end{array}$ \\
\hline 8 & 70 & 37 & 33 \\
Percentage & $52,86 \%$ & $47,14 \%$ \\
\hline
\end{tabular}

The results above imply that students have understood simple present tense with a total of $52.86 \%$. The most seen is that students have correctly placed the use of -s or -es in sentences depending on the subject. As in the sentence: even though she is very busy at work, she never forgets her family. She is good at cooking. She always serves meals for breakfast before I go to campus.

But the result is only a $5.72 \%$ difference or 4 sentences error, so it cannot be said that students really understand Simple Present with a very good level. From a total of 70 
Simple Present Tense, students still make as many as 33 sentences in their writing. Below clearly explained their error which has been classified according to surface strategy taxonomy:

Table 1 Type of Error

\begin{tabular}{|c|c|c|c|}
\hline No & Type of Error & Total Error & Percentage \\
\hline 1 & Omission & 11 & $33,33 \%$ \\
\hline 2 & Addition & 2 & $6,07 \%$ \\
\hline 3 & Mis-formation & 13 & $39,39 \%$ \\
\hline 4 & Mis-ordering & 7 & $21,21 \%$ \\
\hline & Total & 33 & $100 \%$ \\
\hline
\end{tabular}

Based on these results it can be seen that the most errors were in mis-formation of 13 errors (39.39\%). Mis-formation is an error where the use of morpheme or structure is wrong. The most error made by students in using to be, how should is and are used depends on singular or plural. Like when explaining something to someone's body. For example, His skin are white.

Omission became the second most error after mis-formation with $33.33 \%$. Omission is an error that occurs due to the loss of items in a form that is really needed in well-formed. This error is most clearly seen when students omit articles such as a / an and the in a sentence they write. For example, He is employee in company. or My mother is patient woman, she is the best chef ever.

Next, with $21.21 \%$, mis-ordering becomes the third error that's usually done by students. Mis-ordering is an incorrect morpheme placement due to the confusion that happens when composing sentences because students are still stricken by the sentence structure in Indonesian. As an example, She has hair black.

Finally, the least errors created by students are addition. Addition is that the addition of an item that's not needed in grammatical writing. This was only done twice by two totally different students with a total percentage of $6.07 \%$. As an example, My best partners in the world first is my father. For this reason, it's certain to add that nearly all students understand well.

\section{CONCLUSION}

Based on the end result and discussion it may be concluded that students in using the correct simple present when writing descriptive text reached $52.86 \%$. Only a little difference within the total error they are doing is $47.14 \%$. Although the truth percentage is bigger, only a bit totally different from the percentage they create an error. This means that students haven't reached the level that's said to be very good.

The most frequent error they do base on the surface strategy taxonomy is in Misformation with a percentage of $39.39 \%$. The error made by these students was mostly on to be, how they have to adjust plural or singular. Whereas the fewest error in addition. They rarely made these errors, so the percentage error was only at $6.07 \%$.

Writing is an activity that requires good language skills. Often due to limited mastery of grammar, students make language mistakes or errors. Language errors can be seen in many ways. One of them is the surface taxonomy strategy. This taxonomy examines errors in terms of addition, omission, misinformation, and mis-ordering. 
The teachers should give much practice to the use of ending -s or -es in simple present tense and explain how to construct sentences grammatically and appropriately to the students in order to minimize the errors, therefore the students can apply their knowledge of simple present tense directly in the real context of writing.

\section{ACKNOWLEDGMENT}

Alhamdulillah all blessing to God who gave His blessing to the research worker, therefore the research worker can end this article. The researcher would like to say thank you to PGRI University, Jakarta that gave me a chance to publish this article. Additionally, for the blind reviewers who were reviews this article as well as the editorial team, therefore, this article may be published perfectly. The researchers also would really like to mention many thanks to Mu'thia Mubasyira., S.S., S. Hum. as a supervisor who has provided directions, guidance, and correction of this research till this journal was finished on time. The research worker would like to thank my family for his or her supports. First, I would like to express my appreciation to my parents. And second to my big sisters, my big brother who has always supported me. And last thanks to all of my friends.

\section{REFERENCES}

Abdullah, A. (n.d.). error analysis on the use of the simpletense and the simple past tense in writing essays Among TESL college students. International Journal of Education and Research, 1(12).

Hasanah, U. (2015/2016). Error analysis on using simple present tense in writing descriptive text made by the tenth-grade students of SMAN 1 Pace. Kediri: University of Nusantara Kediri.

Juwitasari, R., Raja, P., \& Kadaryanto, B. (2013). An analysis of grammatical errors in using simple present tense in descriptive text writing by students of MAN 1 (Model) Bandar Lampung. U-JET, 2(1).

Lestari, I. (2020). Error Analysis of Simple Present in Writing Descriptive Text. ELTICS: Journal of English Language Teaching and English Linguistics, 5(2).

Muis, I. A. (2019). An Error analysis of using present tense by the tenth grade students of senior high school in writing descriptitive text at MAN 2 Model Medan (Doctoral dissertation, Universitas Islam Negeri Sumatera Utara).

Suhono, S. (2016). Surface strategy taxonomy on the efl students composition a study of error analysis. Jurnal Iqra': Kajian Ilmu Pendidikan, 1(2), 1-30.

Vera, B., Haryudin, A., \& Herdiyanti, W. (2019). Error analysis on the students writing of simple present tense in a descriptive text. PROJECT (Professional Journal of English Education), 2(4), 514-520. 